\title{
Editorial Volume 13
}

\author{
Sabina W. Lautensach ${ }^{1,2,3}$ \\ ${ }^{1}$ Editor-in-Chief of the Journal of Human Security, Librello, Basel, Switzerland \\ 2 Human Security Institute, Canada \\ 3 University of Northern British Columbia, Terrace, BC, V8G 4A2, Canada; E-Mail: salaut@gmail.com
}

Published: 9 February 2017

\section{Dear Reader,}

Those among us who have reached a certain age tend to have developed a long-term perspective and inclination to look back on individual years and to compare them for their respective blessings and injuries. In that sense, 2016 seems to take a special rank as an annus horribilis not just in my own assessment but in numerous commentaries we have come across over the past weeks. Foremost in our awareness featured the surprises: Nobody in my direct acquaintance foretold the Trump phenomenon or the Brexit decision. To find events equally unanticipated and far-reaching, one would have to go back to the 2007/8 financial crash, the $9 / 11$ attacks, the dissolution of the USSR, or the fall of the Berlin Wall in 1989.

How is it that despite unprecedented amounts of meticulous study by legions of specialists those events had not been considered even remotely probable? One obvious handicap shared universally to varying degrees is status quo bias. Another factor that surely played a role, and which is still affecting the judgment of many who ought to know better, is the expectation that most people tend to act rationally in their considered self interest or the interests of their peer groups. This expectation persists in some academic disciplines in spite of overwhelming evidence that demonstrates our susceptibility to cultural norms and subconscious impulses as prime determinants of our behaviour. Despite all rational considerations to the contrary, we seem to cling to the myth that the majority of our peers behave in ways as prudent, informed and precautionary as we consider ourselves to be.

The surprise election of Donald Trump, as well as the Brexit decision, also indicates that polls are less reliable than is widely believed. People seem unwilling to admit their true opinion if they perceive it to be in contradiction to what the media have constructed as the majority view. Trump was elected by voters who would not admit their unwillingness to trust governance to a woman, would not own up to their extent of wholesale disaffection with the system as they perceived it, nor to their general unhappiness with the status quo. Other probable contributing factors were the failure of the Obama administration to hold accountable the culprits of the 2008 financial crash, the worsening stratification and inequity in US society that is creating a new aristocracy [1], and a distrust in the democratic process. Michael Dobbs, the British author of the TV drama House of Cards, claims that the story of President Trump is already written in its entirety in the works of Shakespeare.

The announcement of Trump's electoral victory was followed by a surge of ethnocultural violence across the US, and an ominous sounding blog entitled "and so it begins" which really rang true for me. It reminded me of an election in 1933, perfectly legitimate and democratic (more so than this last one in the US), which through a simple straightforward majority vote brought a government to power that promised the people relief from the status quo. And so it began... only a few years later the same government poured an unprecedented deluge of suffering on the rest of the world. The first learning opportunity in Trump's victory as I see it is the deconstruction of the ubiquitous North American sentiment "it can't happen here". Well-it can, and now it has.

The sobering observation about the abundance of poor judgment among well-informed people also raises the question of what other ominous events are in store for 2017 and beyond that no analyst worth their money would declare 
likely. George Monbiot [2] discussed thirteen "impossible" future crises that could be considered just as unlikely as the unanticipated events discussed above. They include new crises of national banking sectors, the large-scale loss of jobs to automation, growing nationalist and antidemocratic movements, deterioration of agro-ecosystems and its effect on food availability causing the displacement of millions, and the accelerating loss of species and ecosystems. Not all of those processes are reversible; particularly the latter two derive from 'ratcheting' environmental degradation and involve unpredictable tipping points. Monbiot attributes to some of the crises a self-reinforcing property that will result in a rate of change that will take almost everybody by surprise. That is truly frightening because of the unpredictable reactions (from unpredictable rulers and others) and knock-on effects that will eventuate.

For those who care about human security, the challenge is to acknowledge those disheartening prospects and learn as much as possible as quickly as possible. We are truly entering unknown territory regarding what walls will be built, what wars will be fought, where and how the next humanitarian tragedy will unfold. Much of it will not be new but rather resurrected manifestations of old horrors, albeit in new shapes and new orders of magnitude. The prospect of mass starvation looms larger than ever. The main difference with Trump as president will be that in the absence of prudent preventive measures it will arrive sooner and with more hurtful contingencies. The very fate of this presidency seems less certain than its predecessors; it could deteriorate prematurely from its own internal weaknesses and lack of competence; its national support base could melt away or simply persist in its role of vilifying and ridiculing 'Washington'; or the nationwide opposition might coalesce into a movement that brings about not only a new administration but sweeping electoral and political reforms. The wave of protests within the US suggests that such possibilities cannot be dismissed out of hand.

One area of research that manages to illuminate the full spectrum of possible futures in the face of uncertainty is the field of scenario studies. The most comprehensive and inclusive scenario model I have come across is the one that Paul Raskin and coworkers first proposed in 2002[3]. It includes six basic types of global historical development scenarios ('Conventional Worlds', 'Barbarization', 'Great Transitions'), arrived at respectively through the three general pathways of laissez-faire, catastrophic deterioration and proactive reform. The six scenarios can be mutually combined into mixed scenarios or succeed each other. The underlying assumption, as fundamentally significant as it remains widely unrecognised, is that some form of transition to a sustainable future is physically inevitable for humanity. All we can do is nudge the process in one direction or another.

Available pathways to such possible futures are complemented by strategic prescriptions such as Harald Welzer's popular book Selbst Denken: Eine Anleitung zum Widerstand, which translates as "Thinking for Yourself: A Manual for Resistance" (an English translation of the book is un- doubtedly on its way) [4]. Welzer builds on the fundamental fact that human behaviour is first and foremost informed by cultural norms and culturally perpetuated ways of thinking, and only to a minor extent by 'rational' considerations or moral exhortations. In spite of the abundant evidence supporting this fact, it has not yet found adequate recognition in strategic development initiatives, policy priorities, or educational programs. The obvious consequence is the failure of governments to mount any significant changes to their own policies or to affect people's behaviour to reduce the collective ecological overshoot.

If I had to put money on any of Raskin's scenarios, it would be Fortress World. The new US president virtually spelled this one out as his personal vision of the future, most probably without realizing the full implications in their environmental, socio-political and historical dimensions. Fortress World features a widespread impoverishment of the world while a few regions manage to seal themselves off and to preserve a high-impact lifestyle. With borders closing and new barriers arising, people will once again mostly stay in one geographical region. This will have a positive effect on emissions but strengthen parochial and xenophobic sentiments. The most forbidding fortresses will be built in people's minds; their beginnings are evident in public discourse today.

Beyond the US, a frightening number of new electoral outcomes, ranging from ultraright nationalists in Europe through Turkey, Poland and the Philippines, indicate that the decline of democracy has become a worldwide trend. In a recent doctoral dissertation, Aydurmus [5] explored the global trends and sentiments that conspire against democratic decision-making. The trends include increasing resource constraints and population sizes demanding tradeoffs that are difficult to implement democratically. Even more difficult to implement are the kinds of restrictions that are necessary to reverse economic growth and to mitigate ecological overshoot. Democratic principles inform means, not ends; elucidating some of those ends requires the expertise of specialists, even though choosing among them should still be left to democratic decision-making. Democracy is always limited in the sense that not all of those who are affected by decisions actually have a voice, let alone a vote; this inherent incompleteness can give rise to slippery slope arguments against democracy in principle. Finally, popular preferences tend to favour short-term benefits and easily visualised payoffs and reject necessary sacrifices towards long-term payoffs; in many instances, more democracy has not led to more environmental security in a country.

Another factor contributing to the declining confidence in democracy is evident in the widespread failure of governments to live up to public expectations as well as to their own promises. The latest major example of governmental failure is the decision by then UK Prime Minister Cameron to call for a popular referendum on Brexit, which turned out to be a monumental misjudgement, bringing his administration's agenda to a halt and precipitating Cameron's resignation. The Brexit decision is likely to create costs to 
the British taxpayer to the tune of 60 billion euros [2].

An entire wave of misjudgements can be expected as a result of the accumulation of incompetence in Trump's administration [6]. In Welzer's analysis, the roots of governmental failure, even in the hands of competent people, lie in the realisation that, on the one hand, the status quo is becoming increasingly difficult to uphold and, on the other, abandoning status quo ways and means would require systemic innovation harbouring unattractive risks and loss of popularity. This dilemma causes much "hectic fiddling" with status quo structures, barely holding ground much of the time and occasionally failing spectacularly. In a communiqué preceding the 2017 Davos World Economic Forum, it was clearly asserted that the global capitalist economic system is unlikely to survive unless it is substantially revised; I am confident that no such substantial action will be taken, either by the summit powers or any other decision-maker of note.

The cumulative effects of successive government failures are evident in Europe's refugee crisis. Considering how little leadership and organised deliberation on quota and strategies are in evidence, it seems clear that member countries will be unable to mount a concerted response any time soon. In the absence of clear leadership, popular concerns are rising, expediently exploited by those who hope to gain power. The next major wave of refugees can be anticipated as a result of, if not another nearby war, abrupt sea level rise: According to predictions, about fifty million Egyptians from the flooded Nile delta will knock on Europe's doors. The official reaction, I wager, will be utter surprise [7].

The "It will go away-let's go for a coffee" attitude towards serious problems has become apparent in many critical contexts demanding decisive action, ranging from the Greek financial crisis (more loans to tie over the debtors was exactly the wrong thing to do) through climate change, the lost war on drugs, to the appalling mismanagement of the ongoing problems around Fukushima [8].

Some of the reasons for the failure of governments in the face of challenges are probably intrinsic to human nature. Why is it that individuals and small groups are able to revolutionise the lives and security of generations to come, to the point of winning Nobel prizes, while any larger groups easily deteriorate into mobs with collective intelligences akin to that of an earthworm? Politicians whom their system of government obliges to cater to populist inclinations of large groups must address the lowest common denominator, which is often determined by the low collective intelligence of large groups. Appeals to simplistic interpretations of 'freedom' and the promise of 'jobs' and to fight 'terrorism' [9] have worked well in the pro-Trump electorate, while explanations for necessary restrictions would have been pointless and dangerous for his campaign.

While these observations support some of the challenges raised against democracy [5], they do not suffice towards a justification for autocracy, as Thomas Jefferson already pointed out. One reason is that even autocrats strive for popular approval; those of them who do not, risk being deposed by those who do. Doling out bread and games is a favourite on both sides. While they are likely to assuage pro-Trump voters disaffected with the status quo, bread and games are less likely to work with the protesting side because they express their concerns in less materialistic terms. What unites and energises their cause is a concern for human rights. For as long as they are perceived to own that concern they will retain the moral high ground. While the fate of the Occupy movement suggests that superior morals is not sufficient for lasting success, this new protest movement benefits from a continuous supply of easy targets provided to them by their opponents, targets that are readily framed in terms of human rights demands.

History has shown on several dramatic occasions the power of human rights as an ideological propellant to enable popular protest movements to topple hegemonic power structures. However, the advent of the Anthropocene has changed the context of human rights. For the first time in human history we are encountering global constraints that render certain rights ungrantable, including all those whose realisation depends on limited physical resources. Elsewhere [10] we have argued that insisting on ungrantable rights weakens the general power of human rights argumentation.

A case in point regards the ungrantable right to unlimited human reproduction: On 29 October 2015 China officially discontinued its one child policy that had been in force since 1979, preventing about 400 million births. Media responses focused on reproductive human rights and amounted to no more than "too little, too late". Over the years, the critical comments on the Policy followed a predictable humanistlibertarian line that ignored the actual population issue and vehemently proclaimed its purported human rights violations. Analysts seem preoccupied with the demographic consequences of an aging Chinese population, true to the dominant ideology that emphasises economic concepts and values over ecological ones, an ideology that still has not come to grips with global environmental change and systemic limits to growth, four decades after the seminal book on the subject was published. Acknowledging that population reduction cannot fix environmental problems in the short term [11], I assert its paramount importance as a long term determinant of our future.

Fortunately, the kinds of human rights invoked by the antiTrump side are largely of the grantable kind, including gender equity, distributive justice, anti-racism and anti-imperialism. For the time being, the moral high ground appears to be safely in their possession. The next stage of their radicalisation would need to include the experience of their group efficacy, according to Welzer. Their opponent is likely to stoke the flames by criminalising dissent and protest.

In the short term, the rise of Trump-style ultra-right nationalism is likely to reduce government support for Transition initiatives, control of corporate excess and hegemony, and general de-growth and mitigation. From a human security perspective this is no good news, despite the incessant promises of those populist leaders to secure national borders, to make migrants disappear and to ensure universal employment. What will suffer under their leadership are 
the other pillars of human security, most of all their environmental support base. Adaptation and retreat will dominate official policies as the world slides less and less controllably towards catastrophic climates and shortages, bursting economic bubbles and ever larger numbers of displaced people. In the short term, mitigative countermeasures under such regimes will be confined to autonomous initiatives of subcultures and interest groups, local collaborations, community initiatives - united by their counterhegemonic focus. But even beyond such autocratic regimes, more democratic governments tend to fail as well, as we have pointed out.

In the longer term, and in view of the general planetary trends marking the Anthropocene, the ideological orientation of governments will make less difference than their actual accomplishments. Beyond the question which of Raskin's scenarios might gain prominence lies the uncertain fate of the ecosphere and its reduced capacity for supporting the human species. Human impacts and the resulting accelerating ecocide will be the overall determinant of prospects for human security for the remainder of the century. For the first time last fall I read somebody asserting "forget 350!". They are of course correct; it was a faint hope

\section{References and Notes}

[1] Piketty T, Goldhammer A, Ganser L. Capital in the twenty-first century. Cambridge, MA, USA: Harvard University Press; 2014.

[2] Monbiot G. The 13 Impossible Crises that Humanity Now Faces. The Guardian. 2016 Nov 25. Available from: https://www.theguardian.com/commentisfree/2016/nov/25/13crises-we-face-trump-soil-loss-global-collapse.

[3] Raskin P, Banuri T, Gallopin G, Gutman P, Hammond A, Kates R, et al. Great Transition: The Promise and Lure of the Times Ahead. Stockholm Environment Institute; 2002. Polestar Report no. 10. Updated in the Great Transition Initiative: http://www.greattransition.org including an instructional video. Also Raskin P. 2016. Journey to Earthland: The Great Transition to Planetary Civilization. Boston, MA, USA: Paul Raskin / Telus Institute. Available from: http://www.seiinternational.org/publications?pid=1547.

[4] Welzer H. Selbst denken: eine Anleitung zum Widerstand. Frankfurt, Germany: S. Fischer Verlag; 2013.

[5] Aydurmus D. Survival despite the people: Democratic destruction or sustainable meritocracy. The Millennium Alliance for Humanity and the Biosphere; 2017. Available from: http://mahb.stanford.edu/wpcontent/uploads/2016/12/Didem-Aydurmus-Survival-despite-thePeople-Copy-for-Free-Distribution.pdf.

[6] One popular post-inauguration protest sign read "I've seen smarter cabinets at lkea!". Available from: http://www.topprotestsigns.com/ 37/ive_seen_smarter_cabinets_at_ikea.

[7] the White House for the first time warned about the possibility of large numbers of climate refugees. The Guardian. 2016;Https://www.theguardian.com/environment/2016/dec/01/climate- all along. But the ramifications of this insight should be more widely explicated, along with the disclaimer. The race between what tends to pass for 'sustainable development' and population growth is still not widely acknowledged. A recent report in Nature Communications [12] celebrates the finding that our collective ecological footprint has increased at a lower rate than has the global human population hardly a major collective accomplishment but probably coincidental with emerging shortages. Two new reports by the Bertelsmann Stiftung in 2016 specify the SDG Indices for many countries, detailing their performances on all seventeen goals and their subtargets. No mention at all is made of population growth or ecological overshoot. I feel increasingly like a spectator watching a house on fire while the fire service, i.e. governments everywhere, blows hot air instead of water into it. In the midst of that emotion, watching the world's reaction to the Trump inauguration appeared to me as a ray of hope, for now.

Best wishes for a peaceful 2017, Sabina

change-trigger-unimaginable-refugee-crisis-senior-military. https://www.theguardian.com/environment/2016/dec/01/climatechange-trigger-unimaginable-refugee-crisis-senior-military.

[8] Major concerns in Fukushima prefecture include the ongoing information blackout, re-contamination through precipitation and runoff, readjustment of safe exposure levels, compulsory misdiagnosis by doctors (who are gagged on radiation issues), collusion between TEPCO and governmental branches, procedural mis-measurement of real exposure levels (e,g, only to $137 \mathrm{Cs}$ ).and the high tolerance of Japanese society for official corruption: There is no line of critique for Japanese citizens against their government; as soon as someone is elected they are beyond scrutiny (NIRS; Nuclear Information and Resource Service at www.nirs.org).

[9] A recent blog compared the statistical causes of violent death among Americans. While 737 Americans die annually from falling out of bed, only two die from Islamic jihadists. The number who are shot by other Americans is a staggering 11,737. Available from: http://images.huffingtonpost.com/2016-09-01-1472759565493250-extreme_extreme_vetting.jpg.

[10] Lautensach AK. Sustainable Health for All? The Tension Between Human Security and the Right to Health Care. Journal of Human Security. 2015;11(1). doi:10.12924/johs2015.11010005.

[11] Bradshaw CJA, Brook BW. Human population reduction is not a quick fix for environmental problems. Proceedings of the National Academy of Sciences. 2014;111(46):16610-16615. doi:10.1073/pnas.1410465111.

[12] Venter O, Sanderson EW, Magrach A, Allan JR, Beher J, Jones KR, et al. Sixteen years of change in the global terrestrial human footprint and implications for biodiversity conservation. Nature Communications. 2016;7:12558. doi:10.1038/ncomms12558. 